University at Albany, State University of New York

Scholars Archive

2013

\title{
Toward Fostering Environmental Political Participation: Framing an Agenda for Environmental Education Research
}

Brett L. M. Levy

University at Albany, State University of New York, bllevy@albany.edu

Michaela T. Zint

University of Michigan

Follow this and additional works at: https://scholarsarchive.library.albany.edu/etap_fac_scholar

Part of the Education Commons

\section{Recommended Citation}

Levy, Brett L. M. and Zint, Michaela T., "Toward Fostering Environmental Political Participation: Framing an Agenda for Environmental Education Research" (2013). Educational Theory and Practice Faculty Scholarship. 19.

https://scholarsarchive.library.albany.edu/etap_fac_scholar/19

This Article is brought to you for free and open access by the Educational Theory and Practice at Scholars Archive. It has been accepted for inclusion in Educational Theory and Practice Faculty Scholarship by an authorized administrator of Scholars Archive. For more information, please contact scholarsarchive@albany.edu. 
Toward Fostering Environmental Political Participation:

Framing an Agenda for Environmental Education Research

\author{
Brett L. M. Levy \\ University at Albany, State University of New York
}

Michaela T. Zint

University of Michigan 


\begin{abstract}
Scholars of environmental education (EE) and education for sustainable development (ESD) have been among the environmental leaders calling for individuals to become increasingly engaged in political action aimed at addressing environmental and sustainability issues. Few, however, have studied how educational experiences might foster greater environmental political engagement. Fortunately, there is a rich body of research in political science, psychology, and education that provides insights that EE and ESD scholars and educators can build on. Studies in these domains suggest, for example, that political efficacy (the belief that individuals' actions can influence political processes) and political interest (individuals' willingness to pay attention to politics) are strong predictors of political participation. Moreover, these studies have shown that educators can strengthen individuals' political efficacy and interest through activities such as open-ended discussions of political issues, opportunities to identify with politically oriented groups, and involvement in actual and simulated democratic decision-making processes. This conceptual paper (1) reviews the broad support for preparing individuals for environmental political participation through education, (2) synthesizes research on the factors that influence political participation, (3) provides a theoretical framework for researchers and educators interested in fostering environmental political participation, and (4) offers recommendations for descriptive, measurement, and educational studies that can provide educators with further guidance on how to foster individuals' environmental political participation.
\end{abstract}

Keywords: civic engagement; environmental activism; political efficacy; political interest; education for sustainability 
Political action has long played a central role in shaping environmental policies in democratic societies. In the United States, for example, widespread citizen action, including protests, letter writing campaigns, and petitions, played a vital role in the passage of the Clean Air Act and Clean Water Act in the early 1970s (Shabecoff, 2003). Likewise, in Australia, environmental activists leveraged political power to prevent the construction of a dam on the Gordon River in the early 1980s (Doyle \& Kellow, 1995). While some are skeptical of humans' capacity to overcome our environmental crises (Hamilton, 2010), citizens have engaged in numerous successful efforts to persuade their local, state, and national governments to adopt more environmentally sustainable policies (e.g., Hochstetler \& Keck, 2007; Shabecoff, 2003).

We conceptualize environmental political participation as any action that seeks to influence environmental governance, such as voting, community organizing, activism, communicating with public officials, or other forms of public participation. Given the history and potential of such action, leaders from various spheres - including environmental organizations, governmental institutions, and EE and ESD - have recognized the need for broader political participation in environmental issues. For example, the president of the nonpartisan Earth Policy Institute, Lester Brown (2011), recently argued that addressing our environmental crises requires citizens to pressure their governments: "Restructuring the global economy means becoming politically active, working for the needed changes, as the grassroots campaign against coal-fired power plants is doing" (p. 200).

Nonetheless, despite minor fluctuations, citizens in democratic societies, particularly youth, participate in politics at alarmingly low rates (Kirby \& Kawashima-Ginsburg, 2009; Lijphart, 1997), and there has been little research examining how educators can prepare students to actively engage in political issues surrounding sustainability. The major purposes of 
this paper are to describe environmental leaders' ongoing interest in preparing youth for environmental political participation, review research that informs our understanding of how educational programs might foster such participation, and propose related conceptual frameworks and recommendations for future EE and ESD research in this domain.

\section{Broad Interest in Environmental Political Participation}

Since the 1960s, there has been ongoing interest in preparing youth to participate politically to address environmental concerns. For example, when William Stapp and his colleagues (1969) first defined environmental education, they explicitly acknowledged the need to prepare individuals to influence their governments:

Citizens need to understand how to work toward solutions of biophysical environmental problems through laws, public policies, planning ... and institutional arrangements.

Citizens should realize that the responsibility for these problems belongs to them and the governments that represent them. (Stapp et al., 1969, p. 35)

Shortly thereafter, international institutions confirmed this view. In 1977, at the UN-sponsored Intergovernmental Conference on Environmental Education in Tblisi, one major outcome was a consensus report declaring that environmental education should "promote the value and necessity of local, national, and international cooperation in the prevention and solution of environmental problems" (UNESCO, 1978, p. 27). With "participation” as one of its five guiding principles, its authors from around the globe stressed that EE programs should include "multidisciplinary and interdisciplinary approaches" (p. 33), "involvement of the social and human sciences" (p. 45), individual action "at all levels in working toward the resolution of environmental problems" (p. 27), and the development of "new patterns of behavior of individuals, groups, and society as a whole" (p. 26). 
As the scale of environmental problems has worsened, there has been a growing recognition of the need for individuals to address these issues through not only personal behavior change, but also through collective civic action. The 1992 Earth Summit in Rio de Janeiro brought together representatives of 179 countries to draft and sign Agenda 21, which declared that "youth of the world should be mobilized to form a global partnership in order to achieve sustainable development" (U.N. Conference on Environment and Development, 1992, Principle 21). Since then, some national governments have more explicitly endorsed efforts to strengthen environmental political participation. Canada (Government of Canada, 2002), for example, has issued a set of environmental education (EE) goals that include engaging citizens in governmental decision-making processes. The Australian Sustainable Schools Initiative has established citizen-government partnerships for environmental stewardship which, in some cases, provide opportunities for youth to work with local authorities to address environmental problems (Flowers \& Chodkiewicz, 2009). Meanwhile, the UK has considered including citizenship knowledge and skills among its indicators of successful ESD (Huckle, 2009).

The increased attention that national and international institutions are dedicating to preparing individuals for environmental political participation may be related to recent efforts by EE and ESD scholars. Whereas earlier EE scholars and leaders made mostly subtle references to the importance of individuals' engagement in political action (e.g., Sakofs, 1984; Stapp, 1969; UNESCO, 1978), EE and ESD scholars since the mid-1990s have more explicitly emphasized the need to foster such action. In an early exploration of eco-literacy, for example, Volk and McBeth (1997) asserted that environmental educators should aim to develop "informed and capable decision-makers ... who embrace the opportunity to actively and responsibly participate as citizens [in resolving environmental issues].” In a similar vein, Jensen and Schnack (1997), 
who have emphasized the development of action skills, believe that EE should prepare "present and future citizens capable of acting on a societal as well as a personal level" (p. 164). Likewise, Huckle (2001) argues that ESD "should become more concerned with governance and more closely linked to citizenship education” (p. 1).

Building on these arguments, Tilbury $(1995 ; 2011)$ stressed the need for youth to develop democratic skills and values, and she identified political action as a key outcome of ESD.

McKeown-Ice and Dedinger (2000) contend that social science concepts, such as civic ideals and governance, be part of EE in the US. Likewise, Berkowitz, Ford, and Brewer (2005) include civics literacy as one of five key components in their conceptual framework of environmentally responsible behavior for youth.

Although some EE and ESD scholars raise questions about the value of fostering political engagement in systems with unjust power structures (Læssøe, 2010; Kenis \& Mathijs, 2012), a large and growing contingent supports the notion that environmental political participation is an essential component of addressing the challenges of sustainability (Chawla, 2007; Huckle, 2001; Hungerford, 2009; Jensen \& Schnack, 1997; Marcinkowski, 2009; McClaren \& Hammond, 2005; Stapp, Wals, \& Stankorb, 1996). Supporting this perspective, the UN definition of ESD includes the promotion of "democratic and participatory systems" (UNESCO, 2012).

As such, the authors view environmental political participation to be an important goal of EE and ESD. The goal of fostering increased environmental political participation is to empower individuals to share the concerns, interests, and specialized knowledge that they have about their environment with officials and decision-makers whose choices can have substantial consequences for environmental sustainability. As noted above, such participation can take many forms, such as writing letters and emails, demonstrating, and the like. If more individuals became 
involved in such action, public officials would be more likely to respond with policy changes. To keep funding from governmental and non-profit organizations, educational programs are often incentivized to remain apolitical, so many EE and ESD programs do not typically support actions that explicitly favor a particular policy. Nonetheless, we contend that EE and ESD programs can and should prepare students to be politically engaged citizens by fostering the attitudes and skills that will enable them to successfully participate in environmental political action.

\section{Prior Research Related to Environmental Political Participation}

While EE and ESD scholars have highlighted the need for environmental political participation, few have conducted empirical research on the topic. Thus, there are many unanswered questions about how educators can foster environmental political engagement. These observations are based on an extensive review of academic journals in EE and ESD. Using online databases from two research universities, we searched through the archives of the following seven publications during the years indicated (based on availability): Environmental Education Research (1995-2011), Journal of Environmental Education (1997-2011), Environment and Behavior (1969-2011), Journal of Environmental Psychology (1981-2011), Australian Journal of Environmental Education (2005-2011), Journal of Environmental Systems (2004-2011), and Journal of Education for Sustainable Development (2007-2011). In our search, we examined articles in these publications with the following words in the abstract or title: political, civic, action, democracy, and democratic; and we also reviewed several relevant edited volumes, books, and dissertations.

Our review suggests that scholars have thoughtfully explored a number of important issues tangentially related to fostering environmental political participation, including the following: political conflicts over curricula (e.g., Chapman, 2011; Crouch \& Abbot, 2009; 
Holsman, 2001; Lavery \& Smyth, 2003), methods of fostering environmentally responsible behaviors (e.g., Hopper \& Nielsen, 1991; Irvine \& Kaplan, 2001; Katzev \& Mishima, 1992; Mcmakin, 2002; Staats, Harland, \& Wilke, 2003), individual attitudes towards environmental political action (e.g., Hillcoat \& Forge, 1995; Skamp, Boyes, \& Stannistreet, 2009; Uzzell, 2000), optimal environmental activism strategies (Whelan, 2002, 2005), and factors that influence the development of pro-environment attitudes (Arnold, Cohen, \& Warner, 2010; Buttel \& Flinn, 1978; Chawla, 1999; Wohlwill, 1979).

In addition, EE and ESD scholars have examined issues related to political efficacy (Bandura, 1997), a key predictor of political participation (review in following section). For example, EE and ESD scholars have examined methods of fostering self-efficacy (Quimby, Seyala, \& Wolfson, 2007; Moseley, Reinke, \& Bookout, 2002) and locus of control (Hines, Hungerford, \& Tomera, 1986-7; Hsu, 2004; Hwang, Kim, \& Jeng, 2003). Furthermore, some researchers have carefully documented civic action initiatives (some based in educational institutions, some not) that have engaged individuals in addressing local environmental issues, such as local traffic congestion (Carlsson \& Jensen, 2006) and chronic lead contamination (McGee, 1999). These activities and attitudes may be crucial in supporting political efficacy development (Renshon, 1972, 1974).

The limited research that has more directly examined methods of fostering environmental political engagement offers useful insights for educators. Dressner (1990), for example, found that college students who participated in a simulation of a legislative process aimed at energy conservation developed greater political efficacy, a key predictor of various forms of political participation (described more below). Another study explored the effects of middle school students' participation in a multi-week issue investigation and action skills training related to 
wetlands conservation, finding that participants' knowledge of citizenship action skills and perceptions of these skills increased more than those of a control group (Culen \& Volk, 2000). More recently, Kumler (2011) found that high school students whose teachers implemented a land-use curriculum that involved strategic decision-making scenarios expanded their knowledge of possible civic actions.

In addition to studying the civic and political effects of classroom-based programs, researchers have sought to identify factors that are related to environmental political participation. For example, Lubell (2002) found that individuals are more likely to be involved in environmental activism if they prioritize environmental sustainability over economic selfinterest. More recently, a large quantitative study of Green Party members in 18 European countries found that there was greater environmental activism among members who belonged to environmental organizations, or had a history of activism in environmental or other causes (Botetzagias \& van Schuur, 2010). In addition, several studies indicate that when individuals believe that their actions can make a difference, they are more likely to become involved in environmental community action groups (e.g., Manzo \& Weinstein, 1987; Martinez \& McMullen, 2004; Taylor, 1989). Similarly, in a study of California citizens' motivation to participate in community-based efforts to preserve coastal marine life, Weible (2008) found that perceptions of allies' potential effectiveness influenced their decisions to participate.

This research is valuable for educators interested in fostering their students' environmental political participation, but its sparseness and varied outcomes make it difficult for educators or researchers to build a coherent understanding in this domain. Thus, it would be helpful for EE and ESD scholars not only to conduct more studies on the determinants of individuals' environmental political participation but also to engage in research that uses a 
similar set of constructs. In the following section, we describe a range of additional research from the social sciences that can help to frame such future research on enhancing environmental political participation.

\section{Research on the Factors that Influence Political Participation}

The empirical and theoretical work in various social science fields can provide useful insights about how researchers might examine and how educators might prepare students for environmental political participation. During the last several decades, political scientists have examined factors related to political participation, and psychologists have studied diverse aspects of human motivation. Meanwhile, educational researchers have conducted numerous studies on generative classroom contexts. In recent years, scholars from various fields interested specifically in youth civic engagement have conducted an increasing range of studies and published an impressive research handbook (Sherrod, Flanagan, \& Torney-Purta, 2010). Below we synthesize research in these fields that provide the foundation for a preliminary framework for fostering environmental political participation and recommendations for future research that could further our understanding in this area.

\section{Importance of Political Efficacy and Political Interest}

Political scientists have identified numerous factors that contribute to various forms of political participation (e.g., voting, contacting officials, joining political organizations). These factors include political/historical context (Geys, 2006), socioeconomic status (Verba \& Nie, 1972), social connectedness (Putnam, 1995; Robnett, 2007), leadership experience (Damico, Damico, \& Conway, 1998), group identity (Hardy-Fanta, 1993; Wilcox \& Gomez, 1990), and psychological factors (Leighley \& Vedlitz, 1999). While political scientists differ in their research foci, our analysis focuses on two central psychological factors: political efficacy and 
interest. Studies suggest that political efficacy and interest are especially reliable predictors of political participation (Becker, 2004; Cohen, Vigoda, \& Samorly, 2001; Paulsen, 1991; Guyton, 1988; Tygart, 1977; Almond \& Verba, 1963; Stromback \& Shehata, 2010). Moreover, there is strong evidence that educators can positively influence these factors through a variety of strategies (detailed below).

Political efficacy is one of the most closely studied political science constructs and has been defined as:

the feeling that individual political action does have, or can have, an impact upon the political process, i.e., that it is worthwhile to perform one's civic duties. It is the feeling that political and social change is possible, and that the individual citizen can play a part in bringing about this change. (Campbell, Gurin, \& Miller, 1954, p. 187)

Various studies have shown that as political efficacy in populations rises and falls, political participation follows suit (Burnham, 1980; Gibson \& Levine, 2003; Schur, Shields, \& Schriner, 2003). In addition, individuals with high levels of political efficacy have been found to be more likely to vote (Campbell, Converse, Miller, \& Stokes, 1960; Cohen et al., 2001; Pollack, 1983), contact public officials about issues of concern (Hirlinger, 1992; Pollack, 1983; Sharp, 1982), become involved in political activism (Abrams \& DeMoura, 2002; Paulsen, 1991; Tygart, 1977), use informational news media (Newhagen, 1994; Tan, 1981), and become psychologically involved in politics (Bell, 1969; Cohen et al., 2001; See Table 1). Although much of the research on political efficacy has been conducted on the US population, political efficacy has also been found to be an important predictor of political participation in Germany (Becker, 2004), Israel (Cohen, Samorly, \& Vigoda, 2001), and 27 democracies (Karp \& Banducci, 2008). 
Table 1

Studies on the influence of political efficacy on aspects of political participation

\begin{tabular}{|c|c|c|c|c|}
\hline Outcome & Author, Year & Method & Effect Size & Sample Size(s) \\
\hline \multirow[t]{7}{*}{ Voting } & Becker, 2004 & Regression & $\begin{array}{l}.169 * * * \mathrm{EPE} \\
.1 * * * \mathrm{IPE}\end{array}$ & 2052 \\
\hline & Cohen et al., 2001 & LISREL & $.46^{*}$ & 434 \\
\hline & Campbell et al., 1954 & Cross-tabulations & NA & 2200 \\
\hline & Finkel, 1985 & LISREL & $.24 *$ & 1069 \\
\hline & Hanson, 1980 & Loglinear & $\mathrm{NA}$ & $160-703$ \\
\hline & Pollock, 1983 & Regression & $.343 *$ & 1404 \\
\hline & Shaffer, 1981 & Regression & $.11^{*} .21 *$ & $823-1715$ \\
\hline \multirow{3}{*}{$\begin{array}{l}\text { Contacting } \\
\text { Officials }\end{array}$} & Hirlinger, 1992 & Logistic reg. & $.618^{*}$ & 332 \\
\hline & Pollock, 1983 & Regression & $.495 *$ & 1404 \\
\hline & Sharp, 1982 & Cross-tabulations & NA & 363 \\
\hline \multirow{3}{*}{$\begin{array}{l}\text { Political } \\
\text { Activism }\end{array}$} & Paulsen, 1991 & Logistic reg. & $.697^{*}$ & 635 \\
\hline & Pollock, 1983 & Regression & $.395 *$ & 1404 \\
\hline & Tygart, 1977 & Regression & $.19^{*}$ & 877 \\
\hline \multirow[t]{2}{*}{ Media Use } & Newhagen, 1994 & Regression & $.248 * *$ & 343 \\
\hline & Tan, 1981 & Path Analysis & $.148 *$ & 219 \\
\hline \multirow{2}{*}{$\begin{array}{l}\text { Psychological } \\
\text { Involvement in } \\
\text { Politics }\end{array}$} & Bell, 1969 & Simon-Blalock & $\mathrm{NA}$ & Not given \\
\hline & Cohen et al., 2001 & LISREL & $.73^{*}$ & 434 \\
\hline
\end{tabular}

Political interest has been less closely examined than political efficacy, but most researchers have conceptualized it as “citizens' willingness to pay attention to politics at the expense of other endeavors" (e.g., Lupia \& Philpot, 2005, p. 1132). Researchers have found 
political interest to be a strong, consistent predictor of voting (Verba, Schlozman, \& Brady, 1995) and other forms of political participation (Leighley \& Vedlitz, 1999; Stromback \& Shehata, 2009; Verba, Burns, \& Schlozman, 1997). Studies also indicate that political interest influences citizens' amount of political discussion (Pan, Shen, Paek, \& Sun, 2006), awareness of political issues and processes (Van Deth \& Elff, 2004), political knowledge (Stromback \& Shehata, 2009; Delli Karpini \& Keeter, 1996), and exposure to informational news media (Stromback \& Shehata, 2009).

Furthermore, theory and research in psychology and education indicate that political efficacy and interest are important determinants of political participation. For example, studies of the expectancy-value model of motivation have found that when individuals expect to succeed at certain tasks (e.g., political efficacy) and value specific tasks (e.g., political interest), they will be motivated to engage in related tasks (Eccles, 2005; Wigfield \& Eccles, 2000). Also, Ajzen (1985; 1991) has shown that perceived behavioral control, also related to political efficacy, is an important predictor of individuals' actual engagement in behaviors.

Similarly, Bandura (1997) has found that self-efficacy, closely related to political efficacy, influences individuals' willingness to engage in various challenges. Self-efficacy is defined as "a judgment of one's ability to organize and execute given types of performances" (Bandura, 1997, p. 21), and political efficacy is a specific type of self-efficacy. Numerous studies indicate that self-efficacy for particular tasks influences various aspects of performance, including achievement levels (Zimmerman, Bandura, \& Martinez-Pons, 1992; Lent, Brown, \& Larkin, 1986; 1984) and persistence (Lent, Brown, \& Larkin, 1984; Bandura, 2005; BouffardBouchard, Parent, \& Larivee, 1991). 
Thus, research in various social science fields indicates that political efficacy and political interest are particularly important psychological dimensions to consider when educating for political participation. In the following sections, we review current methods for measuring these attitudes and strategies for fostering them.

\section{Measuring Political Interest and Political Efficacy}

To study political efficacy and political interest, researchers have employed a variety of measures. For political efficacy, the majority of scholars have considered political efficacy as a uni-dimensional construct. However, exploratory and confirmatory factor analyses have suggested that political efficacy consists of at least two distinct dimensions: internal political efficacy and external political efficacy (Aish \& Joreskog, 1990; Zimmerman, 1989; Coleman \& Davis, 1976; Balch, 1974). External political efficacy is the belief that individuals can influence governmental decisions and actions whereas internal political efficacy refers to individuals' belief that they can understand politics and competently participate in political acts (Miller, Miller, \& Schneider, 1980).

The most commonly administered items for measuring these two types of political efficacy are used as part of the American National Election Study (NES), a biannual study of a nationally representative sample of US adults (Table 2). The NES has conducted pilot studies of numerous potential political efficacy indicators, and confirmatory factor analyses have identified three items that measure external political efficacy (Craig \& Maggiotto, 1982; Iyengar, 1980; McPherson, Welch, \& Clark, 1977) and seven that measure internal political efficacy (Craig, Niemi, \& Silver, 1990; Niemi, Craig, \& Mattei, 1991).

Additional measurement studies have suggested that individuals' political efficacy can vary based on the level of government (i.e., local, state, national, international) (Langton, 1980; 
Levy, 2013) as well as with the type of public issue (i.e., environmental, criminal, fiscal, etc.) (Levy, 2011). Nonetheless, most researchers studying political efficacy have treated political efficacy as a single, rather than a multi-dimensional,

Table 2

National Election Study items (1990-1998) used to measure external and internal political efficacy

\begin{tabular}{|c|c|}
\hline Factor & Items (5-point agree-disagree Likert type response options) \\
\hline $\begin{array}{l}\text { External } \\
\text { Political } \\
\text { Efficacy }\end{array}$ & $\begin{array}{l}\text { I don't think public officials care much what people like me think. } \\
\text { Generally speaking, those we elect to Congress in Washington lose touch with the people } \\
\text { pretty quickly. }\end{array}$ \\
\hline $\begin{array}{l}\text { Internal } \\
\text { Political } \\
\text { Efficacy }\end{array}$ & $\begin{array}{l}\text { Parties are only interested in people's votes but not in their opinions. } \\
\text { I consider myself well qualified to participate in politics. } \\
\text { I feel that I have a pretty good understanding of the important political issues facing our } \\
\text { country. } \\
\text { Other people seem to have an easier time understanding complicated issues than I do. } \\
\text { I feel that I could do as good a job in public office as most other people. } \\
\text { I often don't feel sure of myself when talking with other people about politics and } \\
\text { government. } \\
\text { I think that I am as well-informed about politics and government as most people. } \\
\text { Sometimes politics and government seem so complicated that a person like me can't } \\
\text { really understand what's going on. }\end{array}$ \\
\hline
\end{tabular}

construct. This lack of specificity prevents us from understanding how, for example, certain activities might influence one type of efficacy more than another, and this could hinder educators' ability to address students' needs. The review that follows therefore only 
distinguishes between different types of political efficacy when the respective authors made such distinctions.

Table 3

Items used to measure political interest

\begin{tabular}{|c|c|}
\hline Source & Items (4- to 7-point Likert type response options ) \\
\hline $\begin{array}{l}\text { National Election } \\
\text { Study (1990-1998) }\end{array}$ & $\begin{array}{l}\text { Some people seem to follow what's going on in government and public affairs most } \\
\text { of the time, whether there's an election going on or not. Others aren't that } \\
\text { interested. Would you say that you follow what's going on in government and public } \\
\text { affairs most of the time, some of the time, only now and then, or hardly at all? } \\
\text { Some people don't pay much attention to political campaigns. How about you? } \\
\text { Would you say that you were very much interested, somewhat interested, or not } \\
\text { much interested in following the political campaigns this year? }\end{array}$ \\
\hline $\begin{array}{l}\text { Lupia and Philpot, } \\
2005\end{array}$ & $\begin{array}{l}\text { [The website I used] makes me want to learn more about politics. } \\
\text { [The website I used] makes me more likely to talk about politics with others. } \\
\text { [The website I used] makes me more likely to vote in the November election. }\end{array}$ \\
\hline $\begin{array}{l}\text { Stromback and } \\
\text { Shehata, } 2010\end{array}$ & Generally speaking, how interested are you in politics? \\
\hline $\begin{array}{l}\text { Kahne, Crow, and } \\
\text { Lee, } 2010\end{array}$ & I am interested in political issues. \\
\hline Levy, 2011 & $\begin{array}{l}\text { Compared to most of your other activities, how useful is learning about political } \\
\text { issues? } \\
\text { For me, being good at understanding political issues is: } \\
\text { How much do you like learning about political issues? }\end{array}$ \\
\hline
\end{tabular}


Items used to measure political interest have varied more than political efficacy measures (Table 3). The NES (1990-1998), for example, asks individuals questions about their interest in recent political campaigns. Other researchers have asked questions that seek to gauge individuals' general political interest (e.g., Marans, Levy, Haven, Bennett, Bush, Doman et al., 2010; Stromback \& Shehata, 2010) or how specific activities relate to individuals' political interest (e.g., Lupia \& Philpot, 2005). The variation in strategies to measure political interest has complicated efforts to build coherent bodies of scholarly knowledge about how to foster it.

\section{Research on Experiences Fostering Political Efficacy and Political Interest}

This section provides an overview of the experiences that political scientists and educational researchers have found to be related to individuals' political efficacy and interest. Among these formative experiences are learning about and discussing political issues, participating in political processes, and identifying with a group, particularly a politically engaged group. Some demographic variables, which may be a proxy for certain experiences, are also related to political efficacy. Although only one of these educational studies was conducted in an environmental context (Dressner, 1990), these findings nonetheless have important implications for civic-oriented EE and ESD.

\section{Learning About and Discussing Political Issues}

Researchers have found that when individuals (adults or children) have opportunities to learn about and discuss political information and perspectives, they are more likely to develop increased levels of political efficacy and political interest. For example, several studies indicate that both political efficacy and interest increase when individuals read newspapers or watch television news (Wells \& Dudash, 2007; Lee, 2006; Kazee, 1981; Kenski \& Stroud, 2006). Also, when children have more opportunities to discuss political issues with peers, their political 
efficacy and interest tend to be higher (Hahn, 1999; Kahne, Crow, \& Lee, 2010; Morrell, 2005). At the same time, however, exposure to confusing or negative political information can decrease external political efficacy (Lee, 2006; Miller, 1979).

These studies suggest that environmental educators may be able to enhance adults' and youth's environmental political efficacy and political interest by providing them with opportunities to learn about and process political information within the context of environmental and sustainability issues, including through interactions with peers. This research also suggests that as part of such learning opportunities, environmental and ESD educators need to clarify complex political realities while avoiding expressing excessive pessimism.

\section{Participation in Political Processes}

Studies suggest that political participation itself can be an effective method of increasing individuals' political efficacy. For many individuals, voting (Ikeda, Kobayashi \& Hoshimoto, 2008; Finkel, 1985) or participating in campaign activities, such as attending political meetings or verbally promoting a party or candidate, can boost political efficacy (Stenner-Day \& Fischle, 1992; Finkel, 1987). Related studies indicate that voting is more likely to promote political efficacy when one's preferred candidate wins (Bowler \& Donovan, 2002; Clarke \& Acock, 1989). Participating in political action in which participants are marginalized or unheard, however, may reduce their political efficacy (Freie, 1997; Stenner-Day \& Fischle, 1992). 
Evidence also indicates that participating in small-scale democratic decision-making processes, especially those that involve skill building, can strengthen political efficacy (Beaumont, 2010). For example, researchers have found that when children are involved in making family decisions, they are more likely to become politically efficacious (Almond \& Verba, 1963; Langton, 1980; Takei \& Kleiman, 1976). In schools, youth have developed higher political efficacy when making classroom rules (Glenn, 1972) and participating in school-wide governance (Siegel, 1977). Similarly, participating in simulations of democratic processes can

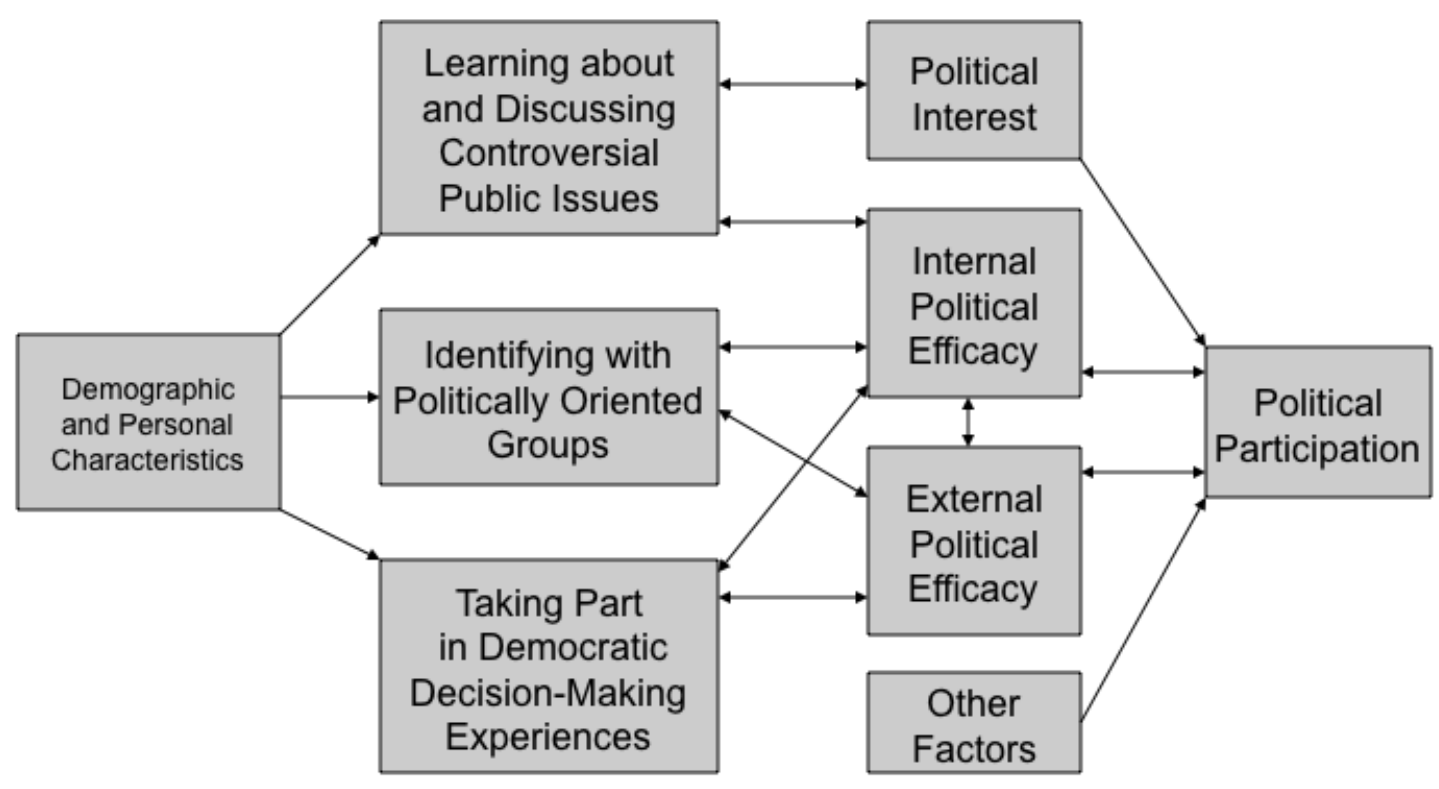

Figure 1. Factors and experiences related to fostering political engagement and participation.

also have positive effects on political efficacy. Researchers have documented political efficacy increases resulting from participation in mock elections (Stroupe \& Sabato, 2004), legislative role-playing games (Boocock, 1968; Vogel, 1973), simulated efforts to design local energy conservation strategies (Dressner, 1990), and debates about potential solutions to international 
challenges (Levy, 2011). Youth's political efficacy can also decrease, however, if they have disempowering simulation experiences (e.g., if the simulation leads to political gridlock) (Livingston, 1972).

Overall, this research suggests that environmental and ESD educators aiming to build adults' and youth's environmental political efficacy may achieve this goal by providing learners with opportunities to have their voices heard on environmental and sustainability issues. Ideally, such opportunities would allow learners to experience some degree of success through real or simulated democratic decision-making processes designed to address environmental or sustainability issues.

\section{Identifying with a Group}

Evidence indicates that identifying strongly with a group, especially a politically-oriented group, can enhance individuals' political engagement. For example, identifying with a political party (Louis, Taylor, \& Neil, 2004), especially the party in power (Lambert, Curtis, Brown, \& Kay, 1986), tends to strengthen individuals' political efficacy. Family politicization also seems to help. When children believe that their parents are interested in political issues, they develop higher political efficacy than other children (Ichilov, 1988; Langton \& Karns, 1969). Researchers have also found that individuals have higher political efficacy if they feel more closely connected to their communities through personal relationships (Steinberger, 1981) or if they identify strongly with a particular demographic group (Koch, 1993). A recent study suggests that having a sense of rapport with politically engaged peers may also enhance youth's political interest (Levy, 2011). Likewise, Beaumont's (2010) analysis of political efficacy research suggests that individuals with supportive relationships, social networks, and close connections to others engaged in political issues can support their development of political efficacy. 
In combination, this evidence suggests that environmental and ESD educators may be able to foster environmental political efficacy and environmental political interest by fostering a sense of belonging through creating supportive groups that are collectively working to address environmental or sustainability challenges.

\section{Demographic Characteristics}

Researchers have also found that certain demographic characteristics are related to political efficacy. For example, studies have consistently found that socioeconomic status, especially educational level, has a strong impact on one's political efficacy (Almond \& Verba, 1963; Ichilov, 1988; Koch, 1993; Lambert et al., 1986; Scott \& Acock, 1979). In addition, individuals develop greater political efficacy as they grow older (Wu, 20003; Koch, 1993; Campbell et al., 1954). This is the case even among young schoolchildren (Glenn, 1972). Intelligence also has a positive effect on political efficacy (Carmines \& Baxter, 1986; Jackman, 1970; White, 1968). Race, however, inconsistently predicts political efficacy (Carmines \& Baxter, 1986; Emig, Hesse, \& Fisher, 1996; Takei \& Kleiman, 1976). Some of these relationships between demographic characteristics and political efficacy may be explained by the different civic education experiences that students with different backgrounds tend to have in schools. Kahne and Middaugh (2008), for example, found that in the USA, students were more likely to experience "best practices" in civic education if they were white, on a higher academic track, and in a school with higher average socioeconomic status.

\section{Synthesis of Research on Political Participation}

Based on this review of research on political participation, we offer the following framework for understanding how educators may be able to foster political participation (Figure 1). As Figure 1 illustrates, political efficacy, political interest, and other factors are directly 
related to political participation. In turn, various educational experiences, such as discussing political issues, having opportunities to identify with politically-oriented groups, and involvement in democratic decision making processes can support the development of political efficacy and interest. There are also a number of potential reciprocal relationships. For example, while political efficacy may foster political participation, the latter may also further strengthen political efficacy. Last, the framework takes into account that individuals with certain demographic characteristics (e.g., white students in high-resource USA schools) are more likely to experience civic EE practices than others.

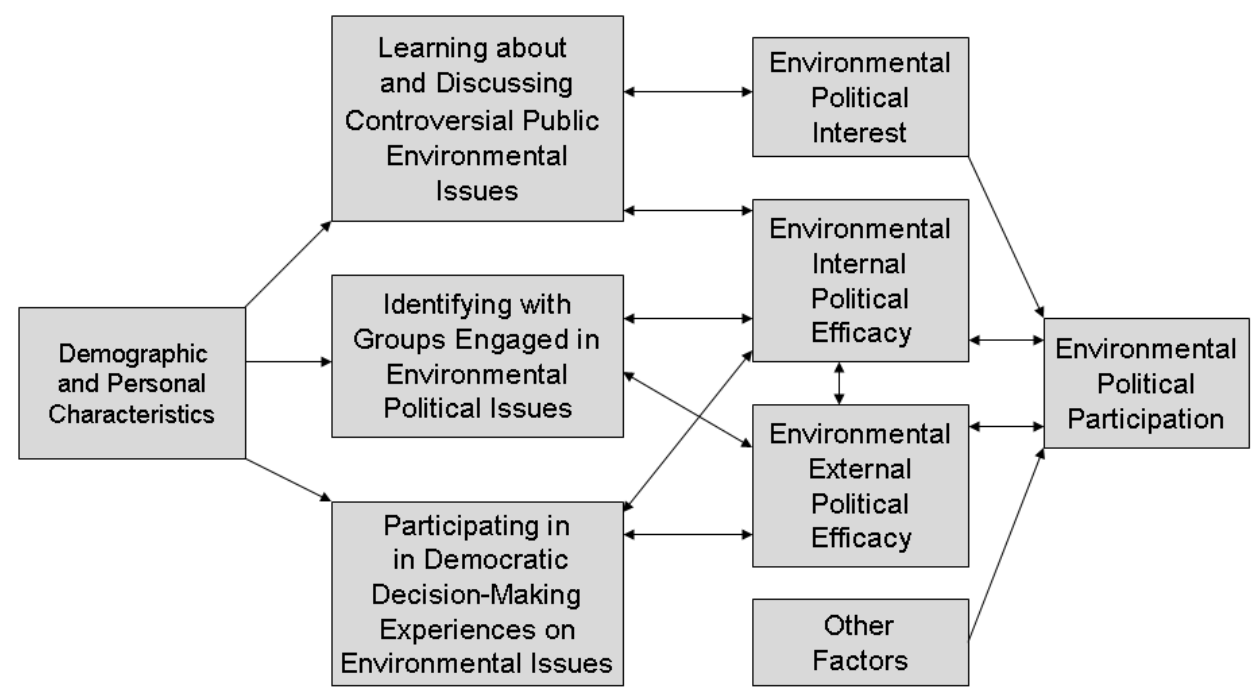

Figure 2. Hypothesized factors and experiences related to fostering environmental political engagement and participation

\section{Hypothesized Model of Factors Related to Fostering Environmental Political Participation}

Although there is limited research on how individuals become engaged in political issues related to the environment and sustainability, it is possible, based on the research described 
above, to hypothesize about the factors and experiences that may foster environmental political participation. Figure 2 below provides domain-specific factors and experiences that may relate to individuals' environmental political participation and thus, offers hypotheses for EE and ESD researchers to explore. Whereas EE and ESD scholars may find the framework useful in guiding research on environmental political participation, educators could find it helpful for identifying relevant instructional activities for politically engaging students.

\section{A Proposed Research Agenda for Environmental Education and ESD Scholars}

Although prior research offers a number of insights into how to foster individuals' political efficacy and interest, studies by EE and ESD scholars are needed to determine to what extent these findings hold in environmental and sustainability contexts. In this section, we propose a research agenda for EE and ESD scholars to consider when examining the factors and educational experiences that might foster individuals' environmental political participation.

First, to understand the factors and sub-dimensions involved in environmental political efficacy and interest, researchers could produce rich descriptions of individuals' conceptions of their desire and capacity to influence governments on environmental and sustainability issues. For environmental political efficacy, the following questions are key: What barriers and opportunities do individuals perceive to influencing environmental policies? Which environmental issues seem most feasible or challenging to address though individuals' political involvement? Do these perceptions differ for individuals of different ages, educational backgrounds, ethnicities, cultural/geographic contexts, or other variables? Studies of environmental political interest might examine questions such as: What environmental and sustainability issues do individuals (of varying ages) consider most compelling, and why? How do individuals first develop an interest in these particular environmental and sustainability 
issues? How does political interest in environmental and sustainability issues grow over time, and how can EE and ESD educators foster it? Through interviews, surveys, and/or other methods, EE and ESD scholars could produce useful descriptions of individuals' environmental political efficacy and environmental political interest that could inform the development of programs to prepare youth for environmental political participation.

To supplement and strengthen this descriptive work, it will be necessary to develop valid and reliable measures of environmental political efficacy and interest. Fortunately, political scientists and educational researchers have developed a variety of items to measure political efficacy and interest that EE and ESD researchers can build on (See Tables 2 and 3). Given the prior use and testing of political efficacy and interest measures (such as items included in the NES), it will likely be beneficial to adapt these measures to environmental and sustainability contexts. For example, one pilot item for environmental internal political efficacy might read, "I consider myself well qualified to participate in political decisions about environmental issues." Likewise, a pilot item of environmental political interest might read: "I am interested in learning more about environmental problems."

Furthermore, because individuals may feel more or less politically efficacious on certain issues or at certain levels of government, it would be useful to have items that account for these distinctions. For example, new questions could measure individuals' internal and external political efficacy for specific environmental challenges, such as climate change, deforestation, fisheries depletion, clean water, and other issues; or they could measure the extent to which respondents believe they could influence environmental regulation at local, state, or national levels. In addition, researchers might consider piloting new types of political efficacy measures, such as those that require participants to indicate their feelings of efficacy in certain hypothetical 
political scenarios (King, Murray, Salomon, \& Tandon, 2004). Moreover, new items for measuring environmental political engagement, which could be integrated into national and international EE and ESD assessments (e.g., Marcinkowski et al., 2012), could be useful when examining the civic outcomes of curricula or experiences focused on different sustainability issues.

With such measures in hand, EE and ESD researchers could also explore the extent to which experiences that have been linked to general political efficacy and political interest (Figure 1) have the potential to foster environmental political efficacy and interest. For example, it would be useful for environmental and ESD educators to know whether or not discussing public issues, related or unrelated to sustainability, positively influences not only general internal political efficacy but also environmental internal political efficacy, or if belonging to a politically engaged group has positive effects on both general and environmental external political efficacy. Similarly, researchers could examine whether or not becoming engaged in environmental political issues facilitates efficacy and interest in other political issues. These are important questions for educators who aim to motivate their students to become engaged in civic and political action, in environmental or sustainability issues or otherwise. Whereas quantitative measures are likely to prove quite valuable in measuring trends, qualitative analyses of observations, interviews and artifacts can strengthen in-depth understanding of how particular experiences influence individuals' environmental political efficacy and thus, of how educators can adjust their pedagogy to strengthen learners' political participation.

There would also be benefits to learning if and how various instructional techniques can influence individuals' likelihood of participating politically in environmental issues. For example, does participation in authentic activities or simulations designed to solve community 
environmental problems positively influence individuals' environmental external political efficacy, internal political efficacy, and/or environmental political interest? Some prior research on fostering general political efficacy suggests that it may. Stroupe and Sabato (2004), for example, found students who participated in Democracy Corps, a program that engages youth in service learning and interactions with local leaders, developed greater political efficacy and knowledge than a comparison group. Yet, individuals may respond differently when grappling with environmental or sustainability issues.

In addition, there are existing EE and ESD programs that could positively influence civic and political outcomes and which could provide a valuable research context. For instance, numerous youth have participated in community problem-solving activities in which they conduct research on a local environmental issue and develop plans to resolve it (e.g., Lewis, 2004; Reid, Jensen, Nikel, \& Simovska, 2007; Stapp, Wals, \& Stankorb, 1996). There are also educational programs in which students examine strategies for supporting endangered species (Gambino, Davis, \& Rowntree, 2009), develop environmental activist skills through online curricula (Sheehan \& Laitenen, 2010), and design environmental education programs (Almlov \& Moberg, 2008). Likewise, youth also participate in efforts to improve their educational institutions' sustainability through developing strategic plans, holding "zero waste" events, and running recycling competitions (e.g., Marans, Levy, Haven, Bennett, Bush, Doman et al., 2010; Levy \& Marans, 2012). Educators interested in preparing youth for environmental political participation would benefit from knowing if these and similar instructional techniques can foster environmental political efficacy or interest. Depending on the nature of such studies' findings, they may help to garner additional support for EE and ESD. 
Understanding how certain experiences beyond those provided by educational institutions influence environmental political engagement may also be useful. Such experiences include volunteering for an environmental organization (Georgia \& Eleni, 2011), participation in community-based environmental decision-making (Nomura \& Abe, 2009; Stephan, 2005; Weible, 2008), involvement in neighborhood revitalization (Semenza \& March, 2009), and local activism for sustainability (Goodman \& Clary, 1976; McGee, 1999). Examining the ways and extent to which these processes may (or may not) support environmental political engagement could be helpful in designing non-formal education programs and in generating support for informal civic and political learning opportunities.

To enhance our broader understanding of how to foster environmental political participation, it is important for researchers to consider complementary lines of research that extend beyond environmental political efficacy and interest. For example, some political science and educational research studies have suggested that having political knowledge and skills can also play a role in fostering political efficacy, interest, and participation (Levy, 2011; Verba, Schlozman, \& Brady, 1995). Also, it is possible that supporting the development of personally responsible environmental behaviors (e.g. Mobley, Vagias, \& DeWard, 2010) could foster environmental political efficacy and that perceptions of environmental risks (e.g., Pidgeon, Kasperson, \& Slovic, 2003) could contribute to environmental political interest. Such lines of research could reveal additional opportunities for fostering students' engagement in civic and political affairs. The types of research proposed within the above contexts, including descriptive, measurement, and educational program studies, could be useful in these complementary domains, as well. 
Finally, given the pragmatic purposes of such research, it would be helpful to understand the challenges involved in developing educators' capacities to employ practices appropriate for supporting youth environmental political engagement, and how to overcome them. First, educators' values and thinking can play an important role in shaping their pedagogy (Hart, 2003). Because educators' prior knowledge may influence their learning (Donovan \& Bransford, 2005), studies of how teachers think about fostering environmental political participation may be useful in designing successful professional development programs that build on educators' prior conceptions. Similarly, educators may have limited experiences leading activities likely to foster environmental political efficacy and interest, such as guiding political discussions or structuring activities involving democratic student participation (Hess, 2009; Kahne, Rodrigues, Smith, \& Thiede, 2000). Thus it would be helpful for researchers to explore how teachers can develop such skills. Evidence suggests that well-planned professional development programs can develop teachers' various capacities, including pedagogical skills (Whitcomb, Borko, \& Liston, 2009) and pro-environment behaviors (Pruneau et al., 2006). Researchers in EE and ESD could help to inform professional developers by studying how educators can develop the capacities necessary for fostering environmental political participation.

\section{Conclusion}

Political participation is essential to addressing humanity's environmental and sustainability challenges. Recognizing this need, EE and ESD scholars have been among the leaders to tout the importance of political participation in environmental and sustainability issues. To date, however, few empirical studies have explored how to prepare youth for environmental political participation. 
Fortunately, existing research by political scientists, psychologists, and educational researchers provides many relevant insights. These studies suggest, for example, that environmental political efficacy and interest are likely to influence environmental political participation and that environmental political efficacy may vary by level of government and type of environmental issue. Also, these studies have identified several experiences that may enhance individuals' environmental political participation, such as learning about the politics of environmental issues and participating in real or simulated political processes on these issues.

It is now up to EE and ESD scholars to examine the extent to which findings from other contexts hold for environmental political participation as well as to identify and study other factors that may be relevant. Such studies will provide environmental and ESD educators with a better understanding of how to prepare students to participate in political processes to address major environmental problems. In addition, researchers could examine how professional development programs could develop EE and ESD teachers' capacities to engage in researchbased practices in this domain. In summary, by conducting descriptive, measurement, and educational studies of environmental political participation and how to foster it, EE and ESD scholars can lay the foundation for strengthening individuals' participation in issues vital to sustaining our planet. 


\section{References}

Abrams, D., \& DeMoura, G. R. (2002). The psychology of collective political protest. In V. C. Ottati, R. F. Tindale, J. Edwards, F. B. Bryant, L. Heath, D. C. O'Connell, Y. Suarez-Balcazar, \& E. J. Posavac (Eds.). The social psychology of politics (pp. 193-214). New York, NY: Springer.

Aish, A.M., \& Joreskog, K.G. (1990). A panel model for political efficacy and responsiveness: An application of LISREL 7 with weighted least squares. Quality and Quantity, 24(4), 405-426.

Ajzen, I. (1985). From intentions to actions: A theory of planned behavior. In J. Kuhl \& J. Beckmann (Eds.). Action control: From cognition to behavior (pp. 11-39). New York, NY: Springer-Verlag.

Ajzen, I. (1991). The theory of planned behavior: Some unresolved issues. Organizational Behavior and Human Decision Processes, 50, 179-211.

Almlov, M., \& Moberg, E. (2008). Students in possession of the issues of tomorrow: An innovative student-led course project. Journal of Education for Sustainable Development, 2(2), 173-179.

Almond, G. \& Verba, S. (1963). The civic culture. Princeton, NJ: Princeton University. American National Election Study (1990-1998). Time-Series studies 1990-1998 variables. Retrieved 8 July 2008 from ftp://ftp.electionstudies.org/ftp/resourcs/questions/1990s.htm

Arnold, H. E., Cohen, F. G., \& Warner, A. (2010). Youth and environmental action: Perspectives of young environmental leaders on their formative influences. Journal of Environmental Education, 40(3), 27-36. 
Balch, G. (1974). Multiple indicators in survey research: The concept 'sense of efficacy'. Political Methodology 1, 1-49.

Baldassare, M. \& Katz, C. (1992). The personal threat of environmental problems as predictor of environmental practices. Environment and Behavior, 24(5), 602-616.

Bandura, A. (2005). Adolescent development from an agentic perspective. In T. Urdan \& F. Pajares (Eds.) Self-efficacy beliefs of adolescents (pp. 1-43). Charlotte, NC: Information Age.

Bandura, A. (1997). Self-efficacy: The exercise of control. New York, NY: Freeman.

Beaumont, E. (2010). Political agency and empowerment: Pathways for developing a sense of political efficacy in young adults. In L. R. Sherrod, J. Torney-Purta, \& C. A. Flanagan (Eds.) Handbook of research on civic engagement in youth (pp. 525-558). Hoboken, NJ: John Wiley \& Sons.

Becker, R. (2005). Political efficacy and voter turnout in East and West Germany. Swiss Political Science Review, 11(1), 57-86.

Bell, R. (1969). The determinants of psychological involvement in politics: A causal analysis. Midwest Journal of Political Science, 13(2), 237-253.

Berkowitz, A.R., Ford, M.E., \& Brewer, C.A. (2005). A framework for integrating ecological literacy, civics literacy, and environmental citizenship in environmental education. In E.A. Johnson \& M.J. Mappin (Eds.) Environmental education and advocacy (pp. 227-266). Cambridge, England: Cambridge University Press.

Boocock, S.S. (1968). An experimental study of the learning effects of two games with simulated environments. In S. Boocock \& E. Schild (Eds.) Simulation games in learning (pp. 107-133). Beverly Hills, CA: Sage. 
Botetzagias, I. \& W. van Schuur (2010). Active greens: An analysis of the determinants of Green Party members' activism in environmental movements. Environment and Behavior 44(4), 1-36.

Bouffard-Bouchard, T., Parent, S., \& Larivee, S. (1991). Influence of self-efficacy on self-regulation and performance among junior and senior high-school age students. International Journal of Behavioral Development, 14, 153-164.

Bowler, S. \& Donovan, T. (2002). Democracy, institutions, and attitudes about citizen influence on government. British Journal of Political Science, 32(2),371-390.

Brown, L.R. (2011). World on the edge. New York, NY: Norton.

Burnham, W.D. (1980). The appearance and disappearance of the American voter. In R. Rose (Ed.) Electoral Participation (pp. 35-74). London: Sage.

Buttel, F. M. \& Flinn, W. L. (1978). The politics of environmental concern: The impact of party identification and political ideology on environmental attitudes. Environment and Behavior, 10(1), 17-36.

Campbell, A., Converse, P., Miller, W., \& Stokes, D. (1960). The American voter. New York, NY: John Wiley.

Campbell, A., Gurin, G., \& Miller, W. (1954). The voter decides. Evanston, IL: Row, Peterson.

Carlsson, M. \& Jensen, B.B. (2006). Encouraging environmental citizenship: The roles and challenges for schools. In A. Dobson \& D. Bell (Eds.) Environmental Citizenship (pp. 237-262). Cambridge, MA: MIT Press.

Carmines, E.G., \& Baxter, D.J. (1986). Race, intelligence and political efficacy among school children. Adolescence, 21(82), 437-442. 
Chapman, D. J. (2011). Environmental education and the politics of curriculum: A national case study. Journal of Environmental Education, 42(3), 193-202.

Chawla, L. (1999). Life paths into effective environmental action. Journal of Environmental Education, 31(1), 15-26.

Chawla, L. (2007). Participation and the ecology of environmental awareness and action. In A. Reid, B. B. Jensen, J. Nikel, \& V. Simovska (Eds.) Participation and learning: Perspectives on the environment and education, health and sustainability (pp. 98-110). London: Springer.

Clarke, H.D., \& Acock, A.C. (1989). National elections and political attitudes: the case of political efficacy. British Journal of Political Science, 19(4), 551-562.

Cohen, A., Vigoda, E. \& Samorly, A. (2001). Analysis of the mediating effect of personal-psychological variables on the relationship between socioeconomic status and political participation: A structural equations framework. Political Psychology, 22(4), 727-757.

Coleman, K. \& Davis, C. (1976). The structural context of politics and dimensions of regime performance: their importance for the comparative study of political efficacy. Comparative Social Studies, 9(2), 189-206.

Craig, S.C., Niemi, R.G., \& Silver, G. E. (1990). Political efficacy and trust: A report on the NES pilot study items. Political Behavior, 12(3), 289-314.

Craig, S.C. \& Maggiotto, M.A. (1982). Measuring political efficacy. Political Methodology, 8, 89-110.

Crouch, R. C. \& Abbot, D. S. (2009). Is green education blue or red? State-level 
environmental education program development through the lens of red- and blue-state politics. Journal of Environmental Education, 40(3), 52-62.

Culen, G. R. \& Volk, T. L. (2000). Effects of extended case study on environmental behavior and associated variables in seventh- and eighth-grade students. Journal of Environmental Education, 31(2), 9-15.

Damico, A. J., Damico, S. B., \& Conway, M. M. (1998). The democratic education of women. Women \& Politics, 19(2), 1-31.

Delli Carpini, M.X. \& Keeter, S. (1996). What Americans know about politics and why it matters. New Haven, CT: Yale University Press.

Donovan, M. S. \& Bransford, J. D. (2005). Introduction. In M. S. Donovan \& J. D. Bransford (Eds.) How Students Learn: History, Mathematics, and Science in the Classroom (pp. 1-28). Washington, DC: National Academies.

Doyle, T. \& Kellow, A. (1995). Environmental politics and policymaking in Australia. South Melbourne: Macmillan Education Australia.

Dressner, M.M. (1990). Changing energy end-use patterns as a means of reducing global warming trends. The Journal of Environmental Education, 21(2), 41-46.

Eccles, J.S. (2005). Subjective task value and the Eccles et al. model of achievementrelated choices. In A.J. Elliot \& C.S. Dweck (Eds.) Handbook of Competence and Motivation (pp. 105-121). New York, NY: Guilford Press. 
Emig, A., Hesse, M., Fisher, S. (1996). Black-white differences in political efficacy, trust, and sociopolitical participation: A critique of the empowerment hypothesis. Urban Affairs Review, 32(2), 264-275.

Finkel, S.E. (1985). Reciprocal Effects of Participation and Political Efficacy: A Panel Analysis. American Journal of Political Science, 29(4), 891-913.

Finkel, S.E. (1987). The Effects of participation on political efficacy and political support: Evidence from a West German panel. Journal of Politics, 49(2), 441-464.

Flowers, R., \& Chodkiewicz, A. (2009). Local communities and schools tackling sustainability and climate change. Australian Journal of Environmental Education, 25, $71-81$.

Freie, J.F. (1997). The effects of campaign participation on political attitudes. Political Behavior, 19(2), 133-156.

Gambino, A., Davis, J., \& Rowntree, N. (2009). Young children learning for the environment: Researching a forest adventure. Australian Journal of Environmental Education, 25, 83-94.

Liarakou, G., Kostelou, E., \& Gavrilakis, C. (2011). Environmental volunteers: factors influencing their involvement in environmental action. Environmental Education Research, 17(5), 651-673.

Goodman, R. F., \& Clary, B. B. (1976). Community attitudes and action in response to airport noise. Environment and Behavior, 8(3), 441-470.

Geys, B. (2006). Explaining voter turnout: A review of aggregate level research. Electoral Studies, 25, 637-663.

Gibson, C., \& Levine, P. (2003). The Civic Mission of the Schools. New York and 
College Park, MD: Carnegie Corporation of New York and Center for Information and Research on Civic Learning and Engagement.

Glenn, A.D. (1972). Elementary school children's attitudes towards politics. In B.G. Massialas (Ed.) Political youth, traditional schools: National and international perspectives (pp. 51-63). Englewood Cliffs, NJ: Prentice Hall.

Government of Canada (2002). A framework for environmental learning and sustainability in Canada. Canada: National Library of Canada.

Guyton, E. (1988). Critical thinking and political participation: Development and assessment of a causal model. Theory and Research in Social Education, 16(1), 23-49.

Hahn, C.L. (1999). Citizenship education: An empirical study of policy, practices, and outcomes. Oxford Review of Education, 25(1-2), 231-250.

Hamilton, C. (2010). Requiem for a species. Washington, DC: Earthscan.

Hardy-Fanta, C. (1993). Latina politics, latino politcs: Gender, culture, and political participation in Boston. Philadelphia, PA: Temple University Press.

Hart, P. (2003). Teachers' thinking in environmental education: Consciousness and responsibility. New York, NY: Peter Lang.

Hess, D. (2009). Controversy in the classroom. New York, NY: Routledge.

Hillcoat, J., \& Forge, K. (1995). 'I think it's really great that someone is listening to us...': Young people and the environment. Environmental Education Research, 1(2), $159-171$. 
Hines, J., Hungerford, H., \& Tomera, A. (1986-7). Analysis and synthesis of research on environmental behavior: A meta-analysis. Journal of Environmental Education, 18, 1-8.

Hirlinger, M.W. (1992). Citizen-initiated contacting of local government officials: A multivariate explanation. The Journal of Politics, 54(2), 553-564.

Hochstetler, K. \& Keck, M. E. (2007). Greening Brazil: Environmental activism in state and society. Durham, NC: Duke University Press.

Holsman, R. H. (2001). The politics of environmental education. Journal of Environmental Education, 32(2), 4-7.

Hopper, J.R., \& Nielsen, J.M. (1991). Recycling as altruistic behavior: Normative and behavioral strategies to expand participation in a community recycling program. Environment and Behavior, 23(2) 195-220.

Hsu, S. (2004). The effects of an environmental education program on responsible environmental behavior and associated environmental literacy variables in Taiwanese college students. Journal of Environmental Education, 35(2) 37-48.

Huckle, J. (2009). Consulting the UK ESD community on an ESD indicator to recommend to government. Environmental Education Research, 15(1) 1-15.

Huckle, J. (2001). Education for sustainability and ecological citizenship in Europe: A challenge for teacher education in the 21 st Century. Paper presented to conference at the University of Thrace, Alexandroupolis, Greece.

Hungerford, H.R. (2009). Environmental education for the $21^{\text {st }}$ century: Where have we 
been? Where are we now? Where are we headed? Journal of Environmental Education, 41(1), 1-6.

Hwang, Y. H., Kim, S. I., \& Jeng, J. M. (2000). Examining the causal relationships among selected antecedents of responsible environmental behavior. The journal of environmental education, 31(4), 19-25.

Ichilov, O. (1988). Family politicization and adolescents' citizenship orientations. Political Psychology, 9(3) 431-444.

Ikeda, K. I., Kobayashi, T., \& Hoshimoto, M. (2008). Does political participation make a difference? The relationship between political choice, civic engagement and political efficacy. Electoral Studies, 27(1), 77-88.

Irvine, K. N., \& Kaplan, S. (2001). Coping with change: the small experiment as a strategic approach to environmental sustainability. Environmental Management, 28(6), 713-725.

Iyengar, S. (1980). Subjective political efficacy as a measure of diffuse support. The Public Opinion Quarterly, 44(2), 249-256.

Jackman, R. W. (1970). A note on intelligence, social class, and political efficacy in children. The Journal of Politics, 32(4), 984-989.

Jensen, B. B., \& Schnack, K. (1997). The action competence approach in environmental education. Environmental education research, 3(2), 163-178.

Karp, J. A., \& Banducci, S. A. (2008). Political efficacy and participation in twentyseven democracies: How electoral systems shape political behaviour. British Journal of Political Science, 38(02), 311-334.

Katzev, R., \& Mishima, H. R. (1992). The use of posted feedback to promote 
recycling. Psychological Reports, 71(1), 259-264.

Kahne, J., Crow, D., \& Lee, N. (2010). Discussion-Based and experiential high school curricula: Their differential impact on civic and political outcomes. Unpublished manuscript, Mills College (Oakland, CA).

Kahne, J. \& Middaugh, E. (2008). Democracy for some: the civic opportunity gap in high school (CIRCLE Working Paper 59). Retrieved from Center for Information \& Research on Civic Learning and Engagement website: http://www.civicyouth.org/PopUps/WorkingPapers/WP59Kahne.pdf

Kahne, J., Rodriguez, M., Smith, B. \& Thiede, K. (2000). Developing citizens for democracy? Assessing opportunities to learn in Chicago's social studies classrooms. Theory and Research in Social Education, 28(3), 311-338.

Kazee, T.A. (1981). Television exposure and attitude change: The impact of political interest. Public Opinion Quarterly, 45, 507-518.

Kenis, A. \& Mathijs, E. (2012). Beyond individual behaviour change: the role of power, knowledge, and strategy in tackling climate change. Environmental Education Research $18(1), 45-65$.

Kenski, K., \& Stroud, N. J. (2006). Connections between Internet use and political efficacy, knowledge, and participation. Journal of broadcasting \& electronic media, 50(2), 173-192.

King, G., Murray, C., Salomon, J. \& Tandon, A. (2004). Enhancing the validity and cross-cultural comparability of measurement in survey research. American Political Science Review, 98(1), 191-207.

Kirby, E. H., \& Kawashima-Ginsberg, K. (2009, August 17). Youth vote in 2008 
(CIRCLE Fact Sheet). Retrieved from Center for Information \& Research on Civic Learning and Engagement website:

http://www.civicyouth.org/PopUps/FactSheets/FS_youth_Voting_2008_updated_6.22.pd f

Koch, J.W. (1993). Assessments of group influence, subjective political competence, and interest group membership. Political Behavior, 15(4), 309-325.

Kumler, L.M. (2011). Students of action?: A comparative investigation of secondary science and social studies students' action repertoires in a land use context. Journal of Environmental Education, 42(1), 14-29.

Lambert, R. D., Curtis, J. E., Brown, S. D., \& Kay, B. J. (1986). Effects of identification with governing parties on feelings of political efficacy and trust. Canadian Journal of Political Science, 19(04), 705-728.

Langton, K.P. (1980). Political participation and learning. North Quincy, MA: Christopher.

Langton, K. P. \& Karns, D. A. (1969). The relative influence of the family, peer group, and school in the development of political efficacy. The Western Political Quarterly, 22(4), 813-826.

Lavery, A. H. \& Smyth, J. C. (2003). Developing environmental education, a review of a Scottish project: International and political influences. Environmental Education Research, 9(3), 359-383.

Læssøe, J. \& Ohman, J. (2010). Learning as democratic action and communication: Framing Danish and Swedish environmental and sustainability education. Environmental Education Research, 16(1), 1-7. 
Lee, K. (2006). Effects of Internet use on college students' political efficacy.

Cyberpsychology \& Behavior, 9(4), 415-422.

Leighley, J.E. \& Vedlitz, A. (1999). Race, ethnicity, and political participation:

Competing models and contrasting explanations. Journal of politics 61(4), 1092-1114.

Lent, R. W., Brown, S. D. \& Larkin, K. C. (1984). Relation of self-efficacy expectations to academic achievement and persistence. Journal of Counseling Psychology, 31, 356362.

Lent, R. W., Brown, S. D., \& Larkin K. C. (1986). Self-efficacy in the prediction of academic performance and perceived career options. Journal of Counseling Psychology $33(3), 265-269$.

Levy, B. L. M. (2011). "I could make a difference”: Research and theory on educating adolescents for political engagement. (Unpublished doctoral dissertation). University of Michigan, Ann Arbor.

Levy, B. L. M. (2013). An empirical exploration of factors related to adolescents' political efficacy. Educational Psychology, 33(3), 357-390.

Levy, B. L. M., \& Marans, R. W. (2012). Towards a campus culture of environmental sustainability: recommendations for a large university. International Journal of Sustainability in Higher Education, 13(4), 365-377.

Lewis, M. E. (2004). A teacher's schoolyard tale: Illuminating the vagaries of practicing participatory action research. Environmental Education Research, 10(1), 80-114.

Lijphart, A. (1997). Unequal participation: Democracy's unresolved dilemma. American Political Science Review, 91(1), 1-14.

Livingston, S. A. (1972). Effects of a legislative simulation game on the political 
attitudes of junior high school students. Simulation and Games, 3, 41-51.

Louis, W. R., Taylor, D. M., \& Neil, T. (2004). Cost-benefit analyses for your group and yourself: The rationality of decision-making in conflict. International Journal of Conflict Management, 15(2), 110-143.

Lubell, M. (2002). Environmental activism as collective action. Environment and Behavior, 34(4), 431-454.

Lupia, A. \& Philpot, T.S. (2005). Views from inside the Net: How websites affect young adults' political interest. Journal of Politics, 67(4), 1122-1142.

Manzo, L. C. \& Weinstein, N. D. (1987). Behavioral commitment to environmental protection: A study of active and nonactive members of the Sierra Club. Environment and Behavior, 19(6), 673-694.

Marans, R. W., Levy, B. M., Haven, C., Bennett, J., Bush, K., Doman, C., . . Janiski, J. (2010). Campus sustainability integrated assessment: Culture team phase 1 report. Retrieved from Graham Institute website: Phase 1 report: http://www.graham.umich.edu/pdf/culture-phase1.pdf

Marcinkowski, T.J. (2009). Contemporary challenges and opportunities in environmental education: Where are we headed and what deserves our attention? Journal of Environmental Education, 41(1), 34-54.

Marcinkowski, T. J., D. Shin, K. Noh, M. Negev, G. Sagy, Y. Garb, et al. (2012). National assessments of environmental literacy: A review, comparison, and analysis. In J. Dillon, M. Brody, B. Stephenson, \& A. Wals (Eds.) International handbook of research in environmental education (pp. 310-330). New York, NY, Routledge.

Martinez, T. A., \& McMullin, S. L. (2004). Factors affecting decisions to volunteer in 
nongovernmental organizations. Environment and Behavior, 36(1), 112-126.

McClaren, M. \& Hammond, B. (2005). Integrating education and action in environmental education. In E.A. Johnson and M.J. Mappin (Eds.) Environmental education and advocacy (pp. 267-291). Cambridge, England: Cambridge University.

McGee, T. K. (1999). Private response and individual action: Community responses to chronic environmental lead contamination. Environment and behavior, 31, 66-83.

McKeown-Ice, R. \& Dedinger, R. (2000). Socio-political-cultural foundations of environmental education. Journal of Environmental Education, 31(4), 37-45.

McMakin, A. (2002). Motivating residents to conserve energy without financial incentives. Environment and Behavior, 34, 848-863.

McPherson, J. M., Welch, S., \& Clark, C. (1977). The stability and reliability of political efficacy: Using path analysis to test alternative models. The American Political Science Review, 71(2), 509-521.

Miller, A. H., Goldenberg, E. N., \& Erbring, L. (1979). Type-set politics: Impact of newspapers on public confidence. American Political Science Review, 73(1), 67-84.

Miller, W. E., Miller, A.H., \& Schneider, E.J. (1980). American national election studies data sourcebook. Cambridge, MA: Harvard.

Mobley, C., Vagias, W. M., \& DeWard, S. L. (2010). Exploring additional determinants of environmentally responsible behavior: The influence of environmental literature and environmental attitudes. Environment and Behavior, 42(4), 420-447.

Morrell, M. E. (2005). Deliberation, democratic decision-making and internal political efficacy. Political Behavior, 27(1), 49-69.

Moseley, C., Reinke, K., \& Bookout, V. (2002). The effect of teaching outdoor 
environmental education on preservice teachers' attitudes towards self-efficacy and outcome expectancy. Journal of Environmental Education, 34(1), 9-15.

Newhagen, J. E. (1994). Self-efficacy and call-in political television show use. Communication Research, 21(3), 366-379.

Niemi, R. G., Craig, S. C., \& Mattei, F. (1991). Measuring internal political efficacy in the1988 National Election Study. The American Political Science Review, 85(4), 14071413.

Nomura, K. \& Abe, O. (2009). The education for sustainable development movement in Japan: A political perspective. Environmental Education Research, 15(4), 483-496.

Pan, Z., Shen, L., Paek, H., and Sun, Y. (2006). Mobilizing political talk in a presidential campaign: An examination of campaign effects in a deliberative framework. Communication Research, 33(5), 315-345.

Paulsen, R. (1991). Education, social class, and participation in collective action. Sociology of Education, 64, 96-110.

Pidgeon, N.F., Kasperson, R. E., \& Slovic, P. (Eds.). (2003). The social amplification of risk. Cambridge, UK: Cambridge UP.

Pollock, P.H. (1983). The participatory consequences of internal and external political efficacy: A research note. Western Political Quarterly, 36(3), 400-409.

Putnam, R. D. (1995). Tuning in, tuning out: The strange disappearance of social capital in America. PS: Political science \& politics, 28(04), 664-683.

Pruneau, D., Doyon, A., Langis, J., Vasseur, L., Ouellet, E., McLaughlin, E., et al. (2006). When teachers adopt environmental behaviors in the aim of protecting the climate. Journal of Environmental Education, 37(3), 3-12. 
Quimby, J.L., Seyala, N.D., \& Wolfson, J.L. (2007). Social cognitive predictors of interest in environmental science: Recommendations for environmental educators. Journal of Environmental Education, 38(3), 43-52.

Reid, A., Jensen, B. B., Nikel, J. \& Simovska, V. (Eds.). (2007). Participation and learning: Perspectives on education and the environment, health and sustainability. New York, NY: Springer.

Renshon, S.A. (1972). The psychological origins of political efficacy: The need for personal control (Unpublished doctoral dissertation). University of Pennsylvania.

Renshon, S. A. (1974). Psychological needs and political behavior a theory of personality and political efficacy. New York, NY: Free Press.

Robnett, B. (2007). Does collective identity matter?: African-American conventional and unconventional political participation. Irvine: Center for the Study of Democracy.

Scott, W.J. \& Acock, A.C. (1979). Socioeconomic status, unemployment experience, and political participation: A disentangling of main and interaction effects. Political Behavior, 1(4), 361-381.

Sakofs, M. (1984). Interpretive programming: Opportunities to promote political action. Journal of Environmental Education, 15(4), 38-9.

Schur, L., Shields, T., \& Schriner, K. (2003). Can I make a difference? Efficacy, employment, and disability. Political Psychology, 24(1), 119-149.

Semenza, J. C. \& March, T. L. (2009). An urban community-based intervention to advance social interactions. Environment and Behavior, 41(1), 22-42.

Shabecoff, P. (2003). A Fierce Green Fire: The American Environmental Movement. Washington, DC: Island. 
Shaffer, S. D. (1981). A multivariate explanation of decreasing turnout in presidential elections, 1960-1976. American Journal of Political Science, 25(1), 68-95.

Sharp, E.B. (1982). Citizen-initiated contacting of government officials and socioeconomic status: Determining the relationship and accounting for it. American Political Science Review, 76(1), 109-115.

Sheehan, M. \& Laitenen, J. (2010). The Earth Charter goes interactive and live with eGLO: Using new media to train youth on both sides of the digital divide. Journal of Education for Sustainable Development, 4(2), 253-258.

Sherrod, L., Torney-Purta, J. \& Flanagan, C. (Eds.) 2010. Handbook of research on civic engagement in youth. Hoboken, N.J.: Wiley.

Siegel, M.E. (1977). Citizenship education in five Massachusetts high schools. Theory and Research in Social Education, 5(2), 25-76.

Skamp, K., Boyes, E. \& Stannistreet, M. (2009). Global warming responses at the primary secondary interface: Students' beliefs and willingness to act. Australian Journal of Environmental Education, 25, 15-30.

Staats, H., Harland, P., \& Wilke, H. (2004). Effecting durable change: A team approach to improve environmental behavior in the household. Environment and Behavior, 36(3), 341-367.

Stapp, W.B., et al. (1969). The concept of environmental education. Journal of Environmental Education, 1(1), 30-31.

Stapp, W.B., Wals, A.E.J. \& Stankorb, S.L. (1996). Environmental education for 
empowerment: Action research and community problem solving. Dubuque, IA:

Kendall/Hunt.

Steinberger, P.J. (1981). Social context and political efficacy. Sociology and Social Research, 65(2), 129-141.

Stenner-Day, K., \& Fischle, M. (1992). The effects of political participation on political efficacy: A simultaneous equations model. Australian Journal of Political Science, 27, 282-305.

Stephan, M. (2005). Democracy in our backyards: A Study of community involvement in administrative decision-making. Environment and Behavior, 37(5), 662-682.

Stromback, J., \& Shehata, A. (2010). Media malaise or virtuous circle? Exploring the causal relationships between news media exposure, political news attention and political interest. European Journal of Political Research, 49, 575-597.

Stroupe, K.S., \& Sabato, L.J. (2004). Politics: The missing link of responsible civic education. (Circle Working Paper 18). Retrieved from http://civicyouth.org/PopUps/WorkingPapers/WP18Stroupe.pdf

Takei, Y., \& Kleiman, M. (1976). Participation and feelings of political efficacy:

An examination of the transference model. Comparative Education Review, 20(3), 38199.

Tan, A. S. (1981). Political participation, diffuse support and perceptions of political efficacy as predictors of mass media use. Communication Monographs, 48(2), 133-145.

Taylor, D. (1989). Blacks and the environment: Towards an explanation of the concern and action gap between blacks and whites. Environment and Behavior, 21(2), 175-205.

Tilbury, D. (1995). Environmental education for sustainability: Defining the new focus of 
environmental education in the 1990s. Environmental education research, 1(2), 195-211.

Tilbury, D. (2011). Education for sustainable development: An expert review of processes and learning. Paris, France: UNESCO.

Tygart, C.E. (1977). The Role of theology among other "Belief" variables for clergy in civil rights activism. Review of Religious Research, 18(3), 271-278.

U. N. Conference on Environment and Development. (1992). Agenda 21. Retrieved from http://habitat.igc.org/agenda21/

UNESCO. (1978). Intergovernmental conference on environmental education. Retrieved from http://unesdoc.unesco.org/images/0003/000327/032763eo.pdf

UNESCO. (2012). Education for sustainable development. Retrieved from http://www.unesco.org/new/en/education/networks/global-networks/aspnet/studyareas/education-for-sustainable-development/

Uzzell, D. L. (2000). The psycho-spatial dimensions of global environmental problems. Journal of Environmental Psychology, 20, 307-318.

Verba, S., Burns, N. \& Schlozman, K.L. (1997). Knowing and caring about politics: Gender and political engagement. Journal of Politics, 59(4), 1051-1072.

Verba, S., \& Nie, N.H. (1972). Participation in America: Political democracy and social equality. New York, NY: Harper and Row.

Verba, S., Schlozman, K.L. \& Brady, H. (1995). Voice and equality: Civic voluntarism in America. Cambridge, MA: Harvard UP.

Vogel, R. (1973). The effect of a simulation game on the attitude of political efficacy. Simulation and Games, 4, 71-79.

Volk, T., \& McBeth, W. (1997). Environmental literacy in the United States. 
Washington, DC: North American Association for Environmental Education.

Weible, C. M. (2008). A Collective Interest Model Approach to Explain the Benefit-Cost expectations of participating in a collaborative institution. Environment and Behavior, $40(1), 24-45$

Wells, S.D., \& Dudash, E.A. (2007). Wha'd'ya know? Examining young voters' political information and efficacy in the 2004 election. American Behavioral Scientist, 50(9), 1280-1289.

Whelan, J. M. (2002). Education and training for effective environmental advocacy. (Unpublished dissertation). Griffith University, South Brisbane, Queensland, Australia.

Whelan, J. M. (2005). Popular education for the environment: Building interest in the educational dimension of social action. Australian Journal of Environmental Education, $21,51-62$.

Whitcomb, J., Borko, H. \& Liston, D. (2009). Growing talent: Promising professional development models and practices. Journal of Teacher Education, 60(3), 207-212.

White, E.S. (1968). Intelligence and sense of political efficacy in children. The Journal of Politics, 30(3), 710-731.

Wigfield, A., \& Eccles, J. S. (2000). Expectancy-value theory of achievement motivation. Contemporary Educational Psychology, 25, 68-81.

Wilcox, C., \& Gomez, L. (1990). Religion, group identification and politics among American blacks. Sociological Analysis, 51(3), 271-85.

Wohlwill, J. C. (1979). The social and political matrix of environmental attitudes: An analysis of the vote on the California Coastal Zone Regulation Act. Environment and Behavior, 11(1), 71-85. 
Wu, C.-L. (2003). Psycho-political correlates of political efficacy: The case of the 1994 New Orleans mayoral election. Journal of Black Studies, 33(6), 729-760.

Zimmerman, M. A. 1989. The Relationship between political efficacy and citizen participation: Construct validation studies. Journal of Personality Assessment, 53(3), 554-66.

Zimmerman, B. J., Bandura, A. \& Martinez-Pons, M. (1992). Self-motivation for academic attainment: the role of self-efficacy beliefs and personal goal-setting. American Educational Research Journal, 29(3), 663-676. 
About the Authors

Brett L.M. Levy is an assistant professor in the Department of Educational Theory and Practice at the University at Albany, State University of New York. His research examines how educational programs and institutions can support individuals' and communities' civic and political engagement, and he works with environmental and civic education programs in various parts of the USA.

Michaela T. Zint is a professor in the School of Natural Resources \& Environment, School of Education, and College of Literature, Science and the Arts at the University of Michigan, USA. She conducts research on human behavior, decision, and persuasion theories in environmental education and communication contexts. She also has expertise in program evaluation and evaluation competency building. 